\title{
Kepastian Hukum Bank Eksekusi Objek Hak Tanggungan Yang Menjadi Sengketa Ketenagakerjaan
}

\author{
Nandang Sunandar \\ Alumni Program Studi Doktor Imu Hukum \\ Pascasarjana Universitas Islam Bandung \\ e-mail: nandang.sunandar@gmail.com
}

\begin{abstract}
Abstrak-Pada prinsipnya, hak tanggungan memberikan hak preferensi (droit de preferen) kepada kreditor tertentu berdasarkan Undang-Undang Nomor 4 Tahun 1996 tentang Hak Tanggungan. Namun, dalam praktiknya pelaksanaan hak tersebut seringkali tidak berfungsi secara efektif. Hal ini terlihat pada keputusan Pengadilan Hubungan Industrial Nomor: 41 / G / 2006 / PHI.Bdg yang menetapkan sita jaminan terhadap objek yang telah dibebani hak tanggungan. Tujuan dari penelitian ini adalah untuk menemukan kepastian hukum tentang eksekusi hak tanggungan yang objeknya menjadi sengketa ketenagakerjaan. Metode pendekatan yang digunakan dalam penelitian ini adalah pendekatan yuridis normatif, dengan mengkaji data sekunder. Hasil penelitian menunjukkan bahwa untuk mendapatkan kepastian hukum dalam pelaksanaan hak tanggungan yang objeknya menjadi sengketa ketenagakerjaan, maka diperlukan kebijakan Ketua Pengadilan Negeri Bandung sebagaimana diatur dalam Pasal 5 ayat (1) UndangUndang Nomor 48 tahun 2009 dan Pasal 463 Reglement op de Rechtsvordering (RV).
\end{abstract}

Kata kunci: Hak Tanggungan, Hak Preferensi, Perselisihan Ketenagakerjaan.

Abstract-Basically, mortgages have the right to give preference rights (droit de preference) to a certain creditor based on the Act Number 4 of 1996 concerning Mortgage Rights. However, in practice the implementation of such Rights often does not work effectively, as the decision of the Industrial Relations Court Number: 41/G/2006/PHI.Bdg stipulated the confiscation of mortgage objects. The purpose of this study is to find legal certainty about the execution of mortgages whose objects become labor disputes. The method used in this study is a normative juridical approach, by reviewing secondary data. The results of the study showed that to get legal certainty in the execution of mortgages whose objects become labor disputes, the Discretion of the Chairperson of the Bandung District Court should be issued as provided by in Article 5 paragraph (1) of the Act Number 48 of 2009 and Article 463 Reglement op de Rechtsvordering $(R V)$.

Keywords: Mortgage, Preference Rights, Labour Dispute.

\section{A. PENDAHULUAN}

Ketersediaan sarana kredit
dalam pembangunan bersifat
mutlak, sebab kehidupan para
pengusaha terutama para

pengusaha kecil dan menengah yang menjadi basis pelaku ekonomi di Indonesia biasanya berhadapan dengan modal yang 
terbatas (Mariam Darus

Badrulzman, 1998:1).

Dalam pemberian fasilitas kredit, perbankan pada dasarnya mengharapkan pelunasan utang yang diperoleh dari hasil usaha debitur. Namun demikian, sebaliknya, tidak dapat dijamin bahwa setiap debitur selalu memperoleh keuntungan dari usahanya. Kendala yang demikian itu bisa disebabkan karena pengaruh keadaan bisnis pada umumnya, maupun faktor kelemahan debitur itu sendiri (Muhammad Djumhana, 2000:298).

Dalam praktik perbankan dikenal istilah perjanjian pokok dan perjanjian tambahan. Perjanjian kredit merupakan perjanjian pokok karena perjanjian kredit berisikan keharusan akan adanya jaminan yang berupa sesuatu atau benda yang berkaitan langsung dengan kredit yang dimohon. Sedangkan perjanjian jaminannya sendiri termasuk perjanjian tambahan (accessoir), karena hanya berisikan jaminan yang tidak berkaitan langsung dengan kredit yang dimohonkan artinya hanya pelengkap utama untuk keamanan pengembaliannya. Dengan demikian, perjanjian jaminan merupakan perjanjian assesoir yaitu perjanjian yang melekat pada perjanjian pokok (seperti perjanjian kredit) atau juga dikatakan perjanjian buntut, karena perjanjian ini tidak berdiri sendiri (Mariam Darus Badrulzman, 1998:68).

Apabila jaminan pokok ternyata kurang memenuhi persyaratan, maka pihak kreditur atau bank akan meminta harta milik debitur untuk dijadikan jaminan tambahan. Baik jaminan pokok maupun jaminan tambahan dapat diikat dengan lembagaIembaga jaminan kebendaan baik berupa hak tanggungan, fidusia maupun gadai. Sedangkan untuk jaminan perorangan biasanya diikat sebagai jaminan tambahan, baik berupa penanggungan (borgtocht), maupun berupa company guaranty.

Dibandingkan dengan perjanjian jaminan perseorangan (personal guaranty) biasanya para 
Nandang Sunandar, Kepastian Hukum Bank Eksekusi Objek Hak Tanggungan Yang Menjadi...

kreditur lebih menyukai perjanjian jaminan kebendaan, karena dalam perjanjian jaminan kebendaan dengan jelas ditentukan benda tertentu yang diikat dalam perjanjian, dan benda tersebut disediakan untuk menjaga terjadinya kredit macet dikemudian hari, yaitu sebagai kepastian atas pelunasan utang, lembaga jaminan kebendaan yang lebih disukai pihak kreditur adalah Hak Tanggungan.

Diadakannya suatu jaminan pada dasarnya tidak lain hanya untuk memberikan suatu kepastian hukum bagi para pihak, khususnya bagi pihak kreditur (Bank) yang telah memberikan pinjaman berupa dana kepada debitur. Untuk memberikan kepastian hukum bagi pemegang Hak Tanggungan, maka harus diberikan Sertifikat Hak Tanggungan sebagai surat tanda bukti pemegang haknya. Salah satu kelebihan dari Sertifikat Hak Tanggungan adalah adanya hak yang diberikan oleh undangundang kepada pemegang Hak Tanggungan berupa Hak Eksekutorial yang sifatnya sama dengan putusan pengadilan yang telah mempunyai kekuatan hukum tetap, hal tersebut sebagaimana diatur dalam Pasal 20 ayat (2) UUHT yang menyatakan bahwa atas kesepakatan pemberi dan pemegang Hak Tanggungan penjualan objek Hak Tanggungan dapat dilaksanakan di bawah tangan, jika dengan demikian itu akan diperoleh harga tertinggi yang menguntungkan semua pihak.

Namun dalam praktiknya, pelaksanaan eksekusi Hak Tanggungan sering tidak berjalan mulus, sebab pemilik Hak Tanggungan (debitur) mempunyai kepentingan lain terhadap objek hak tanggungan yang akan dieksekusi. Seperti halnya dalam kasus yang diangkat dalam tulisan ini yaitu pelaksanaan eksekusi hak tanggungan berkaitan dengan adanya putusan Pengadilan Hubungan Industrial.

Dalam putusan Pengadilan Hubungan Industrial dengan Nomor Perkara: 41/G/2006/PHI.BDG, tertanggal 29 Agustus 2006, menyatakan Putus Hubungan Kerja (PHK) 
antara Para Pekerja Tetap dengan PT. IGKA yang disebabkan oleh tidak diberi upah selama 2 bulan berturut-turut yakni dari bulan Januari sampai Februari 2006, karena perusahaan tidak mampu memberikan upah. Pengadilan menghukum PT. IGKA untuk membayar hak-haknya kepada Para Pekerja Tetap berupa uang pesangon, upah proses, upah lembur dan menyatakan Sita Jaminan pada sebidang tanah dan bangunan milik PT. IGKA.

Hak para pekerja telah dijamin Pasal 165 Undang-Undang No. 13 Tahun 2003 tentang Ketenagakerjaan, yang intinya menyatakan bahwa dalam hal terjadi PHK, pekerja berhak atas uang pesangon sebesar 1 (satu) kali, uang penghargaan masa kerja sebesar 1 (satu) kali dan uang penggantian hak.

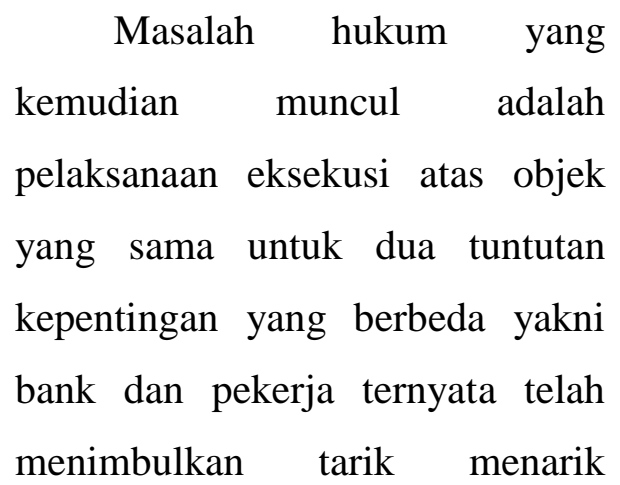

kepentingan di antara kedua belah pihak. Hal tersebut akan mengakibatkan tidak terlaksananya suatu proses eksekusi hak tanggungan yang pelaksanaanya telah dijamin oleh peraturan perundang-undangan, sehingga tidak terciptanya kepastian hukum bagi bank sebagai pemegang Hak Tanggungan.

Berdasarkan atas latar belakang permasalahan diatas, maka dapat diidentifikasikan sebagai berikut:

1. Bagaimana kedudukan Bank sebagai kreditur preferen dalam eksekusi Hak Tanggungan yang objeknya menjadi sengketa ketenagakerjaan?

2. Bagaimana pelaksanaan eksekusi Hak Tanggungan oleh Bank yang objeknya menjadi sengketa ketenagakerjaan?

3. Bagaimana kepastian hukum eksekusi Hak Tanggungan yang objeknya menjadi sengketa ketenagakerjaan?

\section{B. HASIL DAN PEMBAHASAN}

1. Kedudukan Bank Sebagai Kreditur Preferen Dalam 
Eksekusi Hak Tanggungan Yang Objeknya Menjadi

\section{Sengketa Ketenagakerjaan}

Hak Tanggungan merupakan jaminan atas tanah untuk pelunasan utang tertentu yang memberikan kedudukan diutamakan kepada kreditur pemegang hak tanggungan terhadap kreditur-kreditur lainnya. Hak Tanggungan juga tetap membebani objek Hak Tanggungan di tangan siapa pun benda itu berada ini berarti bahwa kreditur pemegang Hak Tanggungan tetap berhak menjual lelang benda yang dijadikan objek jaminan Hak Tanggungan, biarpun sudah dipindahkan haknya kepada pihak lain (droit de suite).

Hak Tanggungan mengikuti obyeknya dalam tangan siapapun obyek Hak Tanggungan itu berada (droit de suite). Berdasarkan Pasal 7 UUHT menetapkan asas bahwa Hak Tanggungan tetap mengikuti obyeknya dalam tangan siapapun obyek tersebut berada. Dengan demikian, Hak Tanggungan tidak akan berakhir sekalipun objek Hak Tanggungan itu beralih kepada pihak lain oleh karena sebab apapun juga. Berdasarkan asas ini, pemegang Hak Tanggungan akan selalu dapat melaksanakan haknya dalam tangan siapapun benda itu berpindah. Asas ini dikenal sebagai droit de suite seperti halnya dalam Hipotik memberikan sifat kepada Hak Tanggungan sebagai hak kebendaan (hak yang mutlak) artinya hak ini dapat dipertahankan terhadap siapapun. Pemegang hak tersebut berhak untuk menuntut siapapun juga yang menganggu haknya itu. Sifat droit de suite disebut juga zaaksgevolg artinya pemegang Hak Tanggungan mempunyai hak mengikuti obyek Hak Tanggungan meskipun obyek Hak Tanggungan telah berpindah dan menjadi pihak lain. Contoh obyek Hak Tanggungan (tanah dan bangunan) telah dijual dan menjadi milik pihak lain, maka kreditur sebagai pemegang jaminan tetap mempunyai hak untuk melakukan eksekusi atas jaminan tersebut jika debitur cidera janji meskipun tanah dan bangunan telah beralih dari 
milik debitur menjadi milik pihak lain (Sutarno, 2003:155).

Kreditur pemegang Hak Tanggungan dalam kedudukannya sebagai kreditur separatis pada prinsipnya mendapat kedudukan didahulukan dibandingkan dengan kreditur-kreditur lainnya. Kedudukan didahulukan ini pada Pasal 1133 ayat (1) KUHPerdata dinyatakan bahwa "hak untuk didahulukan diantara orang-orang berpiutang terbit dari hak istimewa, dari gadai dan dari hipotik", dimana apabila debitur wanprestasi (ingkar janji), kreditur pemegang Hak Tanggungan akan mempunyai hak yang didahulukan dalam pelunasan piutangnya dibandingkan dengan krediturkreditur lainnya yang bukan pemegang Hak Tanggungan.

Adapun mengenai ketentuan pelaksanaan eksekusi objek hak tanggungan secara umum diatur dalam Pasal 20 UUHT yang berbunyi:

(1) "Apabila debitur cidera janji, maka berdasarkan:

a) hak pemegang hak tanggungan pertama untuk menjual objek hak tanggungan sebagaimana dimaksud dalam Pasal 6, atau

b) titel eksekutorial yang terdapat dalam sertifikat hak tanggungan sebagaimana dimaksud Pasal 14 ayat (2). Objek hak tanggungan dijual melalui pelelangan umum menurut tata cara yang ditentukan dalam peraturan perundang-undangan untuk pelunasan piutangpemegang hak tanggungan dengan mendahulu daripadakreditur-kreditur lainnya.

(2) Atas kesepakatan pemberi dan pemegang hak tanggungan, penjualan objek hak tanggungan dapat dilaksanakan di bawah tangan jika dengan demikian itu akan dapat diperoleh harga tertinggi yang menguntungkan semua pihak".

Dari ketentuan tersebut bahwa terdapat 3 (tiga) jenis eksekusi terhadap objek hak tanggungan, yaitu:

a. Parate Eksekusi (Eksekusi Langsung)

Jenis eksekusi ini didasarkan pada ketentuan Pasal 6 UUHT yang menyatakan bahwa: "Apabila debitor cidera janji, pemegang Hak Tanggungan pertama 


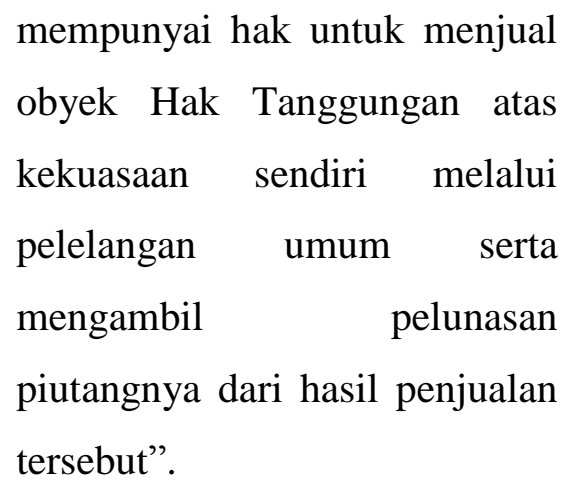

b. Eksekusi melalui Pengadilan Eksekusi ini didasarkan pada Pasal 224 HIR (Pasal 258 $\mathrm{RBg}$ ) yang menyatakan bahwa Pasal 224 HIR (Herzien Inlandsch Reglement): "Surat asli dari pada surat hipotek dan surat hutang yang diperkuat di hadapan notaris di Indonesia dan yang kepalanya memakai perkataan "Atas nama UndangUndang" berkekuatan sama dengan putusan hakim, jika surat yang demikian itu tidak ditepati dengan jalan damai, maka perihal menjalankannya dilangsungkan dengan perintah dan pimpinan ketua pengadilan negeri yang dalam daerah hukumnya orang yang berhutang itu diam atau tinggal atau memilih tempat tinggalnya dengan cara yang dinyatakan pada pasal-pasal di atas dalam bagian ini, akan tetapi dengan pengertian, bahwa paksaan badan itu hanya dapat dilakukan, jika sudah diizinkan dengan keputusan hakim. Jika hal menjalankan keputusan itu harus dijalankan sama sekali atau sebahagian di luar daerah hukum pengadilan negeri, yang ketuanya memerintahkan menjalankan itu, maka peraturan-peraturan pada pasal 195 ayat kedua dan yang berikutnya dituruti." 
Pasal 258 RBg (Reglement Tot

Regeling Van Het Rechtswezen

In De Gewesten Buiten Java En

\section{Madura):}

(1) "Grosse akta hipotek dan surat-surat utang yang dibuat oleh notaris di dalam wilayah Indonesia memuat kepala yang berbunyi "Atas nama Raja" (sekarang: Demi keadilan berdasarkan Ketuhanan yang Maha Esa) mempunyai kekuatan yang sama dengan keputusan pengadilan.

(2) Untuk pelaksanannya yang tidak dijalankan secara suka-rela, berlaku ketentuan-ketentuan bagian ini, tetapi dengan pengertian bahwa penerapan paksaan badan hanya dapat dijalankan jika diizinkan oleh putusan pengadilan".

Atas dasar ketentuan Pasal 224 HIR atau Pasal 258 $\mathrm{RBg}$ tersebut, maka pemegang hak tanggungan dalam melaksanakan eksekusi objek hak tanggungan atas dasar izin dari putusan pengadilan.

c. Eksekusi Penjualan di Bawah Tangan Objek Hak Tanggungan

Secara yuridis eksekusi penjualan di bawah tangan objek hak tanggungan diatur
Pasal 20 ayat (2) dan (3)

UUHT, yang menyatakan bahwa:

(2) Atas kesepakatan pemberi dan pemegang Hak Tanggungan, penjualan obyek Hak Tanggungan dapat dilaksanakan di bawah tangan jika dengan demikian itu akan dapat diperoleh harga tertinggi yang menguntungkan semua pihak.

(3) Pelaksanaan penjualan sebagaimana dimaksud pada ayat (2) hanya dapat dilakukan setelah lewat waktu 1 (satu) bulan sejak diberitahukan secara tertulis oleh pemberi dan/atau pemegang Hak Tanggungan kepada pihakpihak yang berkepentingan dan diumumkan sedikitdikitnya dalam 2 (dua) surat kabar yang beredar di daerah yang bersangkutan dan/atau media massa setempat, serta tidak ada pihak yang menyatakan keberatan.

Dari beberapa jenis eksekusi objek hak tanggungan di atas, tentunya mempunyai suatu tujuan untuk memberikan kepastian hukum bagi pemegang hak tanggungan dalam hal debitur/pemberi hak tanggungan dinyatakan wanprestasi atau telah 
Nandang Sunandar, Kepastian Hukum Bank Eksekusi Objek Hak Tanggungan Yang Menjadi...

dinyatakan tidak dapat lagi memenuhi suatu prestasi.

Adapun yang menjadi pokok permasalaan dalam penelitian ini adalah adanya putusan Pengadilan Hubungan Industrial Nomor: 41/G/2006/PHI.Bdg, yang amarnya menyatakan Pemutusan Hubungan Kerja (PHK) antara Para Penggugat (para buruh yang diwakili oleh Lia Yuliana, dkk) dengan Tergungat (PT. IGKA), terhitung tanggal 29 Agustus 2006, dan menghukum Tergugat untuk membayar hak-haknya kepada Para Penggugat berupa uang pesangon, upah proses, serta upah lembur serta menyatakan Sita Jaminan pada sebidang tanah dan bangunan.

Diketahui bahwa asset perusahaan milik PT. IGKA yang disita oleh Pengadilan Hubungan Industrial ternyata statusnya sedang dibebani hak tanggungan (dalam hal ini Bank Mandiri, selaku pemegang Hak Tanggungan). Oleh karena itu, adanya putusan PHI Nomor: 41/G/2006/PHI.Bdg yang mengadili sengketa ketenagakerjaan, mengakibatkan terhambatnya kepentingan pihak Bank Mandiri selaku pemegang Hak Tanggungan untuk melaksanakan proses eksekusi objek hak tanggungan.

Selanjutnya berdasarkan hasil penelitian diketahui bahwa objek yang disengketakan antara pihak buruh dengan pihak Bank Mandiri selaku pemegang Hak Tanggungan tidaklah mencukupi untuk dibagikan sesuai dengan beban hutang perusahaan baik bagi buruh maupun Bank Mandiri. Sehingga dalam kenyataannya para pihak masing-masing mempunyai dalih untuk melaksanakan terlebih dahulu perolehan hak dari pada asset perusahaan milik PT. IGKA tersebut.

Pada permasalahan hukum seperti ini tentunya memerlukan suatu solusi yang tepat dan bermanfaat bagi kedua belah pihak yang sedang bersengketa dengan tanpa mengabaikan jaminan yang telah diberikan oleh hukum baik bagi pihak buruh selaku pekerja PT. IGKA berdasarkan UndangUndang Nomor 13 Tahun 2003 
Nandang Sunandar, Kepastian Hukum Bank Eksekusi Objek Hak Tanggungan Yang Menjadi...

tentang Ketenagakerjaan maupun Bank Mandiri selaku pemegang Hak Tanggungan selaku kreditur PT. IGKA berdasarkan UndangUndang Nomor 4 Tahun 1996 tentang Hak Tanggungan.

Berikaitan dengan hak buruh menurut Undang-Undang Nomor 13 Tahun 2003 tentang Ketenagakerjaan (selanjutnya disebut UU Ketenagakerjaan) telah diatur mengenai hak mendahului atas pembayaran piutang sebagaimana diatur dalam Pasal 95 ayat (4) UU Ketenagakerjaan yang berbunyi sebagai berikut:

"Dalam hal perusahaan dinyatakan pailit atau dilikuidasi berdasarkan peraturan perundangundangan yang berlaku, maka upah dan hak-hak lainnya dari pekerja/buruh merupakan utang yang didahulukan pembayarannya".

Dalam penjelasan pasal ini diberikan pengertian bahwa yang dimaksud dengan didahulukan pembayarannya adalah upah pekerja/ buruh harus dibayar lebih dahulu dari pada utang lainnya. Berdasarkan ketentuan ini, kedudukan pekerja/ buruh adalah sebagai kreditur apabila terjadi kepailitan, maka hak-hak buruh sama dengan kreditor-kreditor lainnya. Adapun yang menjadi permasalahannya adalah kedudukan buruh sebagai kreditor dalam klasifikasi yang mana (kreditor separatis, preferen, atau konkuren) karena ini akan menentukan urutan prioritas pembayarannya.

Dengan kedudukan bank sebagai pemegang Hak Tanggungan sebagai kreditur preferens maupun kreditur sparatis, tidak menutup kemunginan untuk melaksanakan proses eksekusi terhadap objek hak tanggungan walaupun objek yang akan dieksekusinya tersebut sedang menjadi sengketa ketenagakerjaan. Hal tersebut dikarenakan proses eksekusi terhadap objek hak tanggungan dalam hal debitur wanprestasi atau dinyatakan tidak dapat memenuhi suatu prestasi secara yuridis telah dijamin kepastian hukumnnya dan negara dalam hal ini dapat melindungi kepentingan pihak pemegang hak tanggungan berdasarkan peraturan perundangan-undangan. 
Secara prinsip bahwa kreditur-kreditur lainnya dalam hal kepastian hukum adalah asas dalam negara hukum yang mengutamakan landasan peraturan perundang-undangan, kepatutan, dan keadilan dalam setiap kebijakan Penyelengara Negara. Berdasarkan hal tersebut menurut penulis bahwa kepastian hukum mengandung 3 (tiga) dimensi yaitu peraturan perundang-undangan, kepatutan, dan keadilan. Keadilan merupakan inti dari kepastian hukum yang didukung dengan landasan peraturan perundangundangan dan kepatutan. Berangkat dari argumentasi tersebut, maka Bank sebagai pemegang hak tanggungan secara yuridis dapat melaksanaan proses eksekusi hak tanggungan walaupun objeknya menjadi sengketa ketenagakerjaan. Hal dikarenakan Bank sebagai pemegang hak tanggungan mempunyai kedudukan sebagai Kreditur Preferen yakni mempunyai hak istimewa untuk pelunasan utang tertentu yakni dengan memberikan kedudukan yang diutamakan terhadap ini pihak buruh.

\section{Pelaksanaan Eksekusi Hak} Tanggungan Oleh Bank Yang Objeknya Menjadi Sengketa Ketenagakerjaan

Salah satu langkah yang dilakukan oleh Bank untuk lebih mengamankan dana yang disalurkan kepada masyarakat (nasabah/debitur) yang telah dibebani hak tanggungan ialah melaksanakan eksekusi terhadap objek hak tanggungan. Pada dasarnya eksekusi merupakan upaya pemenuhan prestasi oleh pihak yang kalah kepada pihak yang menang dalam berperkara di Pengadilan. Adapun eksekusi hak tanggungan bukanlah merupakan eksekusi riil, akan tetapi yang berhubungan dengan penjualan dengan cara lelang objek Hak Tanggungan yang kemudian hasil perolehannya dibayarkan kepada Kreditur pemegang Hak Tanggungan, dan apabila ada sisanya dikembalikan kepada Debitur.

Namun dalam kenyataannya diketahui bahwa proses eksekusi 
Hak Tanggungan tidak dapat berjalan dengan lancar, dikarenakan terdapat beberapa hambatan baik hambatan secara yuridis maupun non yuridis.

\section{a. Hambatan Yuridis:}

1) Adanya penjelasan Pasal 20 ayat (1) UUHT yang dapat disimpulkan bahwa Kreditur berhak mengambil pelunasan piutang yang dijamin dari hasil penjualan objek Hak Tanggungan dalam hal hasil penjualan itu lebih besar daripada piutang tersebut yang setinggi-tingginya sebesar nilai tanggungan, sisanya menjadi hak pemberi Hak Tanggungan. Dari ketentuan tersebut berarti utang yang harus dibayar dari uang hasil penjualan lelang objek Hak Tanggungan milik Debitur setinggi-tingginya/maksimal adalah sebesar nilai tanggungan yang disebut dalam Sertifikat Hak Tanggungan itu. Sedangkan biasanya Kreditur menetapkan jumlah lebih besar dari apa yang tertuang dalam Sertifikat Hak Tanggungan, hal ini dikarenakan pada pembebanan Hak Tanggungan ada syaratsyarat, bahwa Debitur sepanjang mengenai besarnya jumlah yang tergantung, harus menerima pembukuan dari pemberi kredit bagi penetapan jumlah yang tergantung itu termasuk bunga dan denda, sehingga jumlahnya bisa melebihi yang tersebut dalam Sertifikat Hak Tanggungan.

2) Kendala lain yang berhubungan dengan janji yang terdapat dalam Pasal 11 ayat (2) huruf j UUHT yaitu janji bahwa pemberi Hak Tanggungan akan mengosongkan objek Hak Tanggungan pada waktu eksekusi Hak Tanggungan. Janji seperti ini oleh Kreditur selalu dimasukkan dalam Sertifikat Hak Tanggungan akan tetapi kebanyakan Debitur tidak akan secara sukarela mengosongkan objek Hak Tanggungan itu baik pada saat objek Hak Tanggungan tersebut akan dieksekusi, sebelum pelelangan maupun setelah pelelangan dilaksanakan.

3) Kendala lain yang sering terjadi yaitu adanya perlawanan oleh pemegang Hak Tanggungan itu sendiri terhadap eksekusi atas permohonan pemegang Hak Tanggungan pertama. Tentang masalah ini tidak diatur dalam UUHT tetapi ada dalam Materi Hukum Acara Perdata.

\section{b. Hambatan Non Yuridis:}

1) Dalam pelaksanaan eksekusi Hak Tanggungan, sering timbul hambatan-hambatan diluar prediksi yaitu pihakpihak Tereksekusi dengan sengaja mengerahkan masanya untuk menghambat jalannya eksekusi, dengan 
cara-cara mengerahkan masa untuk memblokade dan memblokir jalan dan letak objek eksekusi agar Team/Pelaksana Eksekusi tidak bisa masuk kelokasi, serta menghalangi aparat keamanan dengan membakar ban-ban mobil bekas dan ada pula yang sengaja mabukmabukkan sehingga membuat keadaan menjadi gaduh dan kacau dengan berteriak-teriak dan mengumpat Pelaksana Eksekusi dan aparat keamanan, sehingga keadaan menjadi tidak kondusif karena jumlah masa yang lebih banyak dari pada aparat keamanan yang bertugas untuk mengamankan jalannya eksekusi. Keadaan demikian ini membuat repot Pelaksana Eksekusi dan aparat keamanan, sehingga jelas eksekusi tidak bisa dilaksanakan bahkan harus ditunda, karena bila eksekusi dipaksakan atau tetap dilaksanakan bisa-bisa Pelaksana Eksekusi menjadi bulan-bulanan masa pendukung pihak Tereksekusi. Penundaan pelaksanaan eksekusi dimaksudkan untuk menghindari hal-hal yang tidak dikehendaki.

2) Kurangnya pengetahuan masyarakat tentang hukum sehingga mudah dipengaruhi dan diprovokasi oleh pihak Termohon Eksekusi.
Adanya beberapa hambatan tersebut, tentunya akan berakibat pada proses pelelangan objek hak tanggungan berdasarkan putusan KPKNL menjadi tidak dapat dijalankan sama sekali, seperti halnya dalam kasus yang sedang dihadapi oleh PT. Bank Mandiri Cab. Jakarta Thamrin yang terkendala dalam proses eksekusi objek hak tanggungan berupa tanah milik PT. Indo Garment Karunia Abadi (PT. IGKA) dikarenakan adanya sengketa ketenagakerjaan. Sebagaimana telah dijelasakan dalam pembahasan sebelumnya bahwa terjadinya sengketa ketenagakerjaan antara pihak buruh dengan pihak PT. IGKA disebabkan oleh tidak dipenuhinya hak-hak buruh (uang pesangon, uang penghargaan masa kerja dan uang penggantian hak) atas adanya penetapan PHK berdasarkan Putusan PHI serta terkendalanya proses pembayaran hak-hak buruh dikarenakan objek yang dijadikan jaminannya telah dibebani oleh hak tanggungan. Atas adanya kendala dalam proses pembayaran 
Nandang Sunandar, Kepastian Hukum Bank Eksekusi Objek Hak Tanggungan Yang Menjadi...

hak-hak buruh, maka pihak buruh menuntut untuk pembayaran kepada pihak PT. IGKA menggunakan objek yang dijadikan jaminan berdasarkan Putusan PHI. Dengan demikian, maka dengan adanya sengketa ketenagakerjaan tersebut tentunya menjadi kendala dalam proses eksekusi objek hak tanggungan pihak PT. Bank Mandiri Cab. Jakarta Thamrin, sehingga eksekusi hak tanggungan tidak berkepastian hukum.

Berdasarkan hasil penelitan, diketahui bahwa untuk menyelesaikan permasalahan tersebut di atas, telah dilakukan berbagai upaya oleh para pihak yang bersengketa, antara lain:

a. Undangan Pertemuan;

b. Keberatan terhadap Pengumunan Lelang;

c. Adanya Surat Pengantar dari Lembaga Legislatif;

d. Rapat Koordinasi antara para pihak;

e. Upaya hukum lainnya.

Berbagai upaya yang dilakukan oleh para pihak yang mempunyai kepentingan atas objek tersebut tidak melahirkan titik temu, sehingga mengakibatkan lamanya proses eksekusi Hak Tanggungan, dan diketahui bahwa kasus tersebut sampai saat ini belum ada solusi mengenai pembagian asset tersebut dikarenakan masing-masing pihak tidak menerima.

Terdapatnya hak buruh berkaitan dengan objek hak tanggungan, tidaklah mengakibatkan hak preferensi bank sebagai pemegang hak tanggungan menjadi terdahului. Walaupun UU Ketenagakerjaan mengatur adanya hak preferensi bagi buruh. Namun hak preferensi tersebut, terbatas pada perusahaan dinyatakan pailit atau dilikuidasi berdasarkan peraturan perundangundangan yang berlaku sebagaimana diatur dalam Pasal 95 ayat (4) UU Ketenagakerjaan. Oleh karena itu, adanya putusan PHI yang memutuskan penyitaan terhadap asset PT. IGKA yang sedang dibebani hak tanggungan untuk kepentingan buruh, maka secara yuridis tidaklah mempunyai kekuatan dan kepastian hukum.

\section{Kepastian Hukum Eksekusi} Hak Tanggungan Yang 


\section{Objeknya Menjadi Sengketa}

\section{Ketenagakerjaan}

Kepastian hukum merupakan ciri yang tidak dapat dipisahkan dari hukum, terutama untuk norma hukum tertulis (positivisme hukum). Hukum tanpa nilai kepastian akan kehilangan makna, karena tidak lagi dapat dijadikan pedoman perilaku bagi semua orang artinya di mana tiada kepastian hukum di situ tidak ada hukum (ubi jus incertum, ibi jus nullum) (John Rawls, 1973:61).

Menurut Apeldoorn, kepastian hukum mempunyai dua segi. Pertama, mengenai soal dapat ditentukannya (bepaalbaarheid) hukum dalam hal-hal yang konkret artinya pihakpihak yang mencari keadilan ingin mengetahui apakah yang menjadi hukumnya dalam hal yang khusus, sebelum ia memulai suatu perkara. Kedua, kepastian hukum berarti keamanan hukum artinya perlindungan bagi para pihak terhadap kesewenangan hakim.

Dalam hal kepastian hukum bagi bank sebagai pemegang hak tanggungan dapat dibuktikan dengan adanya hak preferensi kreditur dalam pelaksanaan eksekusi sebagaimana diatur dalam UUHT ketika debitur dinilai telah melakukan wanprestasi. Hak preferensi merupakan hak mutlak yang dimiliki oleh kreditur pemegang hak tanggungan untuk melindungi hak kebendaannya. Namun adanya ketentuan mengenai adanya hak preferensi bagi bank, dirasa masih belum dapat melindungi kepentingannya dengan dibuktikan masih adanya hambatan-hambatan dari pihak lain yang mempunyai kepentingan terhadap objek yang telah dibebani hak tanggungan.

Berdasarkan hal tersebut, perlu juga adanya kepastian hukum bank sebagai kreditur preferen dalam hal terdapat putusan Pengadilan Hubungan Industrial Nomor: $\quad$ 41/G/2006/PHI.Bdg berkaitan dengan objek hak tanggungan. Hal tersebut dikarenakan bahwa dalam kenyataannya sampai saat ini, permasalahan mengenai perebutannya objek/barang yang telah dibebani hak tanggungan 
Nandang Sunandar, Kepastian Hukum Bank Eksekusi Objek Hak Tanggungan Yang Menjadi...

oleh pihak buruh melalui putusan PHI Nomor: 41/G/2006/PHI.Bdg belumlah mencapai titik terang penyelesaian. Adanya persepsi mengenai ketentuan pihak mana yang harus terlebih dahulu mendapat pelunasan, mengakibatkan persoalan ini tidak selesai. Oleh karena untuk menjamin kepastian hukum dalam eksekusi hak tanggungan yang objeknya menjadi sengketa ketenagakerjaan diperlukan keterlibatan dari pihak Pengadilan Negeri (PN Bandung) melalui diskresi Ketua Pengadilan Negeri.

Berkaitan dengan diskresi, Alvina Treut Burrows menyatakan bahwa: discreation ability to choose wisely or to jugde one self (kemampuan untuk memilih secara bijaksana atau mempertimbangkan bagi diri sendiri) (Neufeldt, Tt:99). Selanjutnya Prajudi Atmosoedirdjo menerjemahkan diskresi/discreation sebagai kebebasan bertindak atau mengambil keputusan menurut pendapat sendiri (Prakoso, Djoko, 1987:180).
Dari beberapa definisi di atas dapat dinyatakan bahwa pengertian diskresi itu mencakup kewenangan yang bersifat merdeka untuk mengambil keputusan yang tepat/ sesuai dengan situasi dan kondisi yang dihadapi, tidak berdasarkan ketentuan-ketentuan peraturan, undang-undang atau hukum yang berlaku tetapi atas dasar kebijaksanaan, pertimbangan atau keadilan.

Selain dalam bidang hukum, diskresi juga dikenal dalam institusi yang lain. Misalnya juga ditemukan dalam bidang administrasi negara dan institusi kepolisian. Diskresi dalam bidang administrasi negara dikenal dengan istilah freis ermessen. Freis Ermessen berarti salah satu sarana yang memberikan ruang gerak bagi pejabat atau badan administrasi negara untuk melakukan tindakan tanpa harus terikat sepenuhnya pada undang-undang. Diskresi (freies ermessen) adalah kebebasan bertindak atau mengambil keputusan pada pejabat publik yang berwenang berdasarkan pendapat sendiri. Diskresi 
Nandang Sunandar, Kepastian Hukum Bank Eksekusi Objek Hak Tanggungan Yang Menjadi...

diperlukan sebagai pelengkap asas legalitas, yaitu asas hukum yang menyatakan bahwa setiap tindak atau perbuatan administrasi negara harus berdasarkan ketentuan undang-undang, akan tetapi tidak mungkin bagi undang-undang untuk mengatur segala macam hal dalam praktik kehidupan seharihari. Oleh sebab itu diperlukan adanya kebebasan atau diskresi pada pejabat publik dalam melaksanakan tugas, fungsi dan kewajiban yang dibebankan kepadanya

(www.zuryawanisvandiarzoebir.

\section{blogspot.com).}

Keputusan hakim sering kali mendahului penggunaan prinsipprinsip hukum yang formal. Keputusan pengadilan dan doktrin hukum selalu dapat dikembangkan untuk menunjang perkembangan atau hasil-hasil proses hukum. Keputusan pengadilan dibuat berdasarkan konsepsi-konsepsi hakim yang bersangkutan tentang keadilan dan dirasionalisasikan dalam pendapat tertulis. Ahli-ahli hukum dari aliran ini menaruh perhatian yang sangat besar tentang keadilan walaupun mereka berpendapat secara ilmiah tidak dapat ditentukan apa yang dinamakan hukum yang adil (www.zuryawanisvandiarzoebir. blogspot.com).

Dalam sistem hukum Civil Law, diskresi ini muncul sebagai alternatif untuk mengisi kekurangan dan kelemahan dalam penerapan azas legalitas. Sedangkan bagi negara yang bersifat Welfare State, asas legalitas saja tidak cukup untuk dapat berperan secara maksimal dalam melayani kepentingan masyarakat yang berkembang pesat sejalan dengan kemajuan ilmu pengetahuan dan teknologi. Adapun pertimbangan lainnya adalah adanya realitas bahwa suatu kebijakan atau peraturan tidak mungkin mampu merespons banyak aspek dan kepentingan semua pihak sebagai akibat adanya keterbatasan prediksi para aktor atau stakeholders dalam proses perumusan suatu kebijakan atau peraturan (Agus Dwiyanto dkk, 2002). 
Secara historis Indonesia dijajahan oleh Belanda dan mewarisi sistem hukum Belanda. Di sisi lain Indonesia tidak bisa terlepas dari pengaruh global sistem hukum yang ada di dunia ini. Oleh Karena itu Indonesia dapat dikatakan tidak mutlak lagi menganut sistem hukum Civil Law, akan tapi bagi Indonesia berjalan juga dengan dasar-dasar lain yang mewarnai berhukumnya.

Kelaziman di Indonesia, hakim yang satu memakai undangundang sebagai dasar keputusannya, hakim yang lain memakai "rasa" sebagai dasar keputusannya, yang lain memakai hukum Adat sebagai dasar keputusannya, dan ada lagi yang mendasarkannya kepada yurisprudensi. Hal tersebut dilakukan mengingat adanya ketentuan Pasal 5 ayat (1) UndangUndang No. 48 Tahun 2009 tentang Kekuasaan Kehakiman, yang secara jelas menyatakan bahwa hakim dan juga semua penegak hukum dan keadilan wajib menggali, mengikuti dan memahami nilai yang hidup dalam masyarakat. Hal ini tentunya memberi peluang kepada semua hakim di Indonesia untuk memperbaiki citra miring terhadap berhukumnya bagi sistem yang berkembang di Indonesia.

Kemudian apabila pendefinisian diskresi dikaitkan dengan masalah penetapan hukum tentu saja muaranya kebijaksanaan yang diambil oleh hakim dalam memutuskan perkara di antara para pihak yang bersengketa. Berikut ini berapa contoh perkara hukum yang terkait dengan kewenangan diskresi (Agus Dwiyanto dkk, 2002):

a. Keputusan kontroversial Bismar, hukuman pidana bagi pengedar ganja ketika dia menjabat Ketua Pengadilan Tinggi di Medan. Seorang terdakwa yang dituntut jaksa 10 bulan penjara, Bismar melipatgandakannya menjadi 10 tahun. Yang 15 bulan menjadi 15 tahun. Karena itu, dia sangat prihatin dengan keputusan hakim yang menjatuhkan hukuman hanya 4 tahun penjara kepada ratu ekstasi Zarima. Padahal, Zarima tertangkap membawa 29 ribu pil setan. Apakah hakim itu tidak mengetahui dan merasakan akibat dari perbuatan Zarima. Jika Bismar yang jadi hakimnya, Zarima layak 
dihukum mati. Mestinya bikin shock therapy buat pengedar narkoba.

b. Kasus Cut Mariana dan Bachtiar Tahir yang oleh Pengadilan Negeri Medan dihukum 10 bulan penjara karena dituduh memperdagangkan $161 \quad \mathrm{~kg}$ ganja. Vonis ini kemudian diubah Bismar yang waktu itu menjabat Ketua Pengadilan Tinggi Sumatera Utara, menjadi 15 dan 10 tahun penjara.

c. Kemudian hukuman 7 bulan penjara yang dijatuhkan Pengadilan Negeri Tanjung Balai terhadap kepala sebuah SMP Negeri di Kisaran, Sumatera Utara, yang dituduh berbuat cabul dengan anak didiknya, diubah Bismar menjadi 3 tahun penjara. Statusnya sebagai pegawai negeri juga dicabut. Bismar sebagai Ketua Pengadilan Tinggi Sumatera Utara, menafsirkan kata barang dalam Pasal 378 KUHP yang dituduhkan dilanggar oleh terdakwa bisa berarti "jasa". Ini dikaitkannya dengan istilah "bonda" (barang) dalam bahasa Tapanuli, yang juga bisa berarti alat kelamin. Jadi, bila Saksi menyerahkan kehormatannya kepada terdakwa sama dengan menyerahkan "bonda", ujar Bismar berdalih.

d. Kasus kendaraan pribadi yang diperbolehkan masuk jalur busway pada jalur lalu lintas yang padat atau jika pebaikan jalan pada lintasan tersebut. e. Saat banjir melanda Jakarta, jalan tol dibuka untuk semua jenis kendaraan.

f. Putusan hakim Agung Adi Andojo Soetjipto adalah salah satu contoh, yaitu saat mengadili kasasi Muchtar Pakpahan di masa pemerintahan Soeharto. Oleh pengadilan di bawah, Pakpahan dijatuhi pidana atas tuduhan berbuat makar, yaitu kejahatan terhadap negara. Dalam tingkat kasasi MA mengatakan, Pakpahan tidak melakukan perbuatan makar. Menurut MA, para hakim di bawah telah melakukan penerapan hukum yang salah dengan menggunakan yurisprudensi yang sudah ada sejak zaman kolonial. Itu secara sosiologis tidak benar karena Indonesia sudah menjadi negara merdeka dan sudah mulai menjalankan demokrasi dan memperhatikan hak asasi manusia.

Untuk mengatur hal-hal yang lebih rinci dari pelaksanaan suatu ketentuan undang-undang, menurut Muchsan bahwa hakim, pelaksana administrasi negara, juga kepolisian diberikan kebebasan untuk mengambil keputusan berdasarkan pendapat sendiri, namun ini tidak berarti tidak ada rambu-rambu atau koridor-koridor hukum yang membatasinya. Adapun 
pembatasan penggunaan diskresi tersebut adalah (Muchsan, 1981):

a. Tidak boleh bertentangan dengan sistem hukum yang berlaku (kaedah hukum positif).

b. Ditujukan untuk kepentingan umum

Kemudian dalam diskresi terdapat unsur-unsur yang perlu diketahui sebagaimana pendapat Sjachran Basah yang mengemukakan unsur-unsur diskresi antara lain, (Sjachran

Basah, 1985) yaitu:

a. Tindakan itu untuk kepentingan publik;

b. Tindakan itu dimungkinkan oleh hukum;

c. Tindakan itu diambil untuk menyelesaikan persoalanpersoalan yang dianggap krusial.

d. Tindakan ini dapat dipertanggungjawabkan secara moral kepada Tuhan maupun secara hukum.

Lebih lanjut Prajudi Atmosudirdjo mengemukakan bahwa pada prinsipnya pembuatan keputusan yang dibuat oleh pejabat publik terikat pada 3 (tiga) asas hukum, (Prajudi Atmosudirdjo, 1982) yaitu: a. Asas yuridikitas (rechtsmatigheid), artinya keputusan pemerintah tidak boleh melanggar hukum;

b. Asas legalitas (wetmatigheid), artinya keputusan pemerintah harus diambil berdasarkan suatu ketentuan perundang-undangan;

c. Asas diskresi (freies ermessen), artinya pejabat publik tidak boleh menolak mengambil keputusan dengan alasan tidak ada peraturannya, dan oleh karena itu diberi kebebasan untuk mengambil keputusan menurut pendapatnya sendiri asalkan tidak melanggar asas yuridikitas dan asas legalitas tersebut di atas.

Pemerintah atau dalam hal ini pejabat publik diberikan kebebasan untuk mengambil keputusan berdasarkan pendapat sendiri (hakim), namun ini tidak berarti tidak ada rambu-rambu atau koridor-koridor hukum yang membatasinya. Pendapat pribadinya tersebut tetap harus merupakan pengejawantahan undang-undang yang melandasinya tersebut, kemudian asas moralitas dan rasa keadilan masyarakat seharusnya tetap menjiwai kewenangan diskresinya.

Penerapan kewenangan diskresi ini berdasarkan: demi kepentingan umum, masih dalam 
Nandang Sunandar, Kepastian Hukum Bank Eksekusi Objek Hak Tanggungan Yang Menjadi...

batas wilayah kewenangannya, dan tidak melanggar Asas hukum yang belaku. Mungkin secara hukum mungkin ia melanggar, tetapi secara asas ia tidak melanggar kepentingan umum dan hal ini merupakan instant decision (tanpa rencana) dan itu bukan pelanggaran tindak pidana.

$$
\text { Satjipto }
$$

Rahardjo menyatakan seorang pejabat publik tidak melaksanakan peraturan tertulis secara "hitam putih", melainkan selalu bertanya, apakah yang dilakukannya sudah baik untuk masyarakat. Penegak hukum bukan mesin otomat undangundang dan prosedur. Tetapi selalu dihantui keinginan untuk memberikan keadilan kepada masyarakat (bringing justice to the people) sehingga pengadilan menjadi pengadilan yang murni, memiliki nurani (court with conscience). Dengan kata lain ketika memutuskan suatu perkara selain menggunakan logika peraturan, hakim juga mempertimbangkan logika kepautan sosial (social reasonableness) dan logika keadilan.

Dari uraian-uraian di atas dapat digarisbawahi pemberlakuan diskresi bahwa tolok ukur kewenangan tersebut:

a. Tidak bertentangan dengan sistem hukum yang berlaku (kaedah hukum positif);

b. Ditujukan untuk kepentingan umum;

c. Tindakan itu diambil untuk menyelesaikan persoalanpersoalan yang dianggap krusial;

d. Tindakan ini dapat dipertanggungjawabkan secara moral kepada Tuhan maupun secara hukum;

e. Asas moralitas;

f. Rasa keadilan yang berkembang di tengah-tengah masyarakat.

Diskresi secara teoritis adalah penyimpangan. Tindakan diskresi apakah dianggap baik atau buruk sebenarnya bukanlah substansi yang perlu dipersoalkan. Sisi positif diskresi apabila diterapkan pada konteks masyarakat yang dinamis akan sangat membantu untuk melakukan berbagai penyesuaian. Sehingga peraturan yang ada tetap mampu menjawab tuntutan aspirasi dan dinamika masyarakat yang berkembang. Diskresi itu 
Nandang Sunandar, Kepastian Hukum Bank Eksekusi Objek Hak Tanggungan Yang Menjadi...

ibarat pisau bermata dua. Di satu sisi bersifat positif apabila diterapkan pada konteks masyarakat yang dinamis akan sangat membantu untuk melakukan berbagai penyesuaian.

Dalam wacana hukum Islam dikenal adanya istilah ijtihad (proses penggalian hukum Islam). Ijtihad ini dilakukan oleh seorang yang dikategorikan sebagai mujtahid (ahli hukum Islam) dalam menjawab problematika hukum Islam yang terjadi di tengahtengah masyarakat. Proses kreatif ini dapat dianalogikan dengan proses seorang hakim dalam tugasnya dalam memutuskan perkara hukum.

Ada beberapa metode ijtihad yang dapat ditempuh oleh para mujtahid dalam proses penggalian hukum Islam. Terkait dengan bahasan kita tentang diskresi hukum, maka yang akan disinggung berikut ini dibatasi pada metode ijtihad yang memungkinkan terjadinya diskresi hukum.

Menurut penelusuran yang penulis lakukan, dalam beberapa metode ijtihad dimungkinkan terdapat kasus-kasus yang diputuskan dengan diskresi. Ini adalah sebuah indikasi awal bahwa para mujtahid itu tidak terpaku begitu saja terhadap ayat al-Qur'an dan hadis nabi secara literalis. Tetapi mereka juga mempertimbangkan azas-azas, maksud dan tujuan dibalik teks nash tersebut. Sehingga ketika menetapkan suatu hukum, boleh jadi mereka "keluar" dari ketentuan yang secara eksplisit terdapat dalam al-Qur'an dan Sunah. Pada dasarnya ijtihad itu dilakukan oleh para ulama mujtahid berlandaskan maqshid asy-syari'ah; yaitu memelihara agama, jiwa, harta, kehormatan, dan keturunan pada tataran dharuri, haji dan tahsini.

Berdasarkan penjelasan mengenai diskresi tersebut, maka pada prinsipnya bahwa dalam hal ini Ketua Pengadilan Negeri (PN Bandung) dapat menyelesaikan permasalahan hukum terkait pelaksanaan eksekusi hak tanggungan yang objeknya menjadi sengketa ketenagakerjaan, 
Nandang Sunandar, Kepastian Hukum Bank Eksekusi Objek Hak Tanggungan Yang Menjadi...

yakni menggunakan diskresi semata-mata untuk kepentingan umum dan memberikan rasa keadilan serta kepastian hukum yang dilakukan dengan memanggil para pihak untuk musyawarah mufakat dalam pelaksanaan eksekusi hak tanggungan yang objeknya menjadi sengketa ketenagakerjaan.

Dilaksanakannya kegiatan musyawarah yang dipimpin oleh Ketua Pengadilan Negeri tidak lain bertujuan untuk memberikan suatu kepastian hukum bagi para pihak khususnya Bank sebagai pemegang hak tanggungan yang secara yuridis mempunyai kedudukan hukum sebagai Kreditur Preferen sebagaimana diatur dalam Undang-Undang No. 4 Tahun 1996 tentang Hak Tanggungan dan Kitab UndangUndang Hukum Perdata, yang mana dalam tahap implementasinya pihak Bank selaku pemegang hak tanggungan dapat melaksanakan upaya eksekusi objek hak tanggungan baik secara parate eksekusi, eksekusi melalui pengadilan maupun eksekusi di bawah tangan. Musyawarah untuk mufakat pada dasarnya salah satu ciri khas dari bangsa Indonesia yang terkandung dalam Pancasila sila keempat. Tujuan tersendiri adanya musyawarah untuk mufakat ialah membentuk rakyat yang harmonis, erat akan kekelurgaan, dan semangat kebersamaan. Untuk menyelesaiakan permasalahan hukum terkait pelaksanaan eksekusi hak tanggungan yang objeknya menjadi sengketa ketenagakerjaan melaui musyawarah yang difalisitasi oleh Ketua Pengadilan Negeri haruslah mengedepankan prinsip musyawarah untuk mufakat dengan cepat, tepat dan adil.

Pada prinsipnya bahwa penggunaan diskresi dapat dilakukan oleh Ketua Pengadilan Negeri kepada para pihak yang bersengketa semata-mata untuk kepentingan umum dan memberikan rasa keadilan serta kepastian hukum. Dengan adanya diskresi tersebut, maka Ketua Pengadilan Negeri dapat 
Nandang Sunandar, Kepastian Hukum Bank Eksekusi Objek Hak Tanggungan Yang Menjadi...

menetapkan Sita Persamaan atas

Objek Hak Tanggungan yang statusnya sedang dipermasalahkan.

Secara yuridis Sita Persamaan atau Vergelijkend Beslag, diatur dalam Pasal $463 \mathrm{Rv}$ (Reglement op de Rechtvordering) sebagai berikut:

"Apabila juru sita akan melakukan penyitaan dan menemukan barang-barang yang akan disita sebelumnya telah disita, maka juru sita tidak dapat melakukan penyitaan lagi. Namun juru sita mempunyai wewenangan untuk mempersamakan barangbarang yang disita dengan Berita Acara Penyitaan yang harus diperlihatkan oleh tersita kepadanya. Juru sita kemudian dapat menyita barang-barang yang tidak disebut dalam Berita Acara itu dan segera kepada penyita pertama untuk menjual barangbarang tersebut secara bersamaan dalam waktu sebagaimana ditentukan dalam Pasal $466 \mathrm{Rv}$. Berita Acara sita persamaan ini berlaku sebagai sarana pencegahan hasil lelang kepada penyita pertama".

Sita persamaan tidak diatur dalam HIR maupun R. Bg, tetapi diatur dalam Pasal $463 \mathrm{Rv}$ yang mengatur tentang eksekusi barang bergerak. Namun demikian telah berkembang dalam praktek bahwa sita persamaan itu dapat saja dilakukan terhadap barang tidak bergerak, yang tata caranya mengikuti ketentuan dalam Pasal 463 Rv. Ketentuan yang hampir serupa terdapat dalam Pasal 11 ayat (12) Undang-Undang PUPN, Undang-Undang No. 49 Tahun 1960, sebagai berikut:

"Atas barang yang terlebih dahulu disita untuk orang lain yang berpiutang tidak dapat dilakukan penyitaan. Jika jurusita mendapatkan barang yang demikian, ia dapat memberikan salinan putusan Surat paksa sebelum tanggal penjualan tersebut kepada Hakim Pengadilan Negeri yang selanjutnya menentukan bahwa penyitaan yang dilakukan atas barang itu akan juga dipergunakan sebagai jaminan untuk pembayaran hutang menurut Surat paksa.

Apabila setelah dilakukan penyitaan, tetapi sebelum dilakukan penjualan barang yang disita diajukan permintaan untuk melaksanakan suatu putusan Hakim yang ditujukan terhadap penanggung hutang kepada Negara, maka penyitaan yang telah dilakukan itu dipergunakan juga sebagai jaminan untuk pembayaran hutang menuntut putusan Hakim 
itu dan Hakim Pengadilan Negeri

jika perlu memberi perintah untuk melanjutkan penyitaan atas sekian banyak barang yang belum disita terlebih dahulu, sehingga akan dapat mencukupi untuk membayar jumlah uang menurut putusanputusan itu dan biaya penyitaan lanjutan itu.

Hakim Pengadilan Negeri menentukan cara pembagian hasil penjualan antara pelaksana dan orang yang berpiutang, setelah mengadakan pemeriksaan atau melakukan panggilan selayaknya terhadap penanggung hutang kepada Negara, pelaksana dan orang yang berpiutang. Pelaksanaan dan orang yang berpiutang yang menghadap atas panggilan termaksud dalam ayat (3), dapat meminta banding pada Pengadilan Tinggi atas penentuan pembagian tersebut. Segera setelah putusan tentang pembagian tersebut mendapat kekuatan pasti, maka Hakim Pengadilan Negeri mengirimkan suatu daftar pembagian kepada juru lelang atau orang yang ditugaskan melakukan penjualan umum untuk dipergunakan sebagai dasar pembagian uang penjualan. Oleh karena Pasal tersebut berhubungan dengan penyitaan yang dilakukan oleh PUPN, maka sita tersebut adalah sita eksekusi dan bukan sita jaminan, dan objek yang disita bisa barang bergerak atau barang tidak bergerak.

Sita persamaan barang tidak bergerak harus dilaporkan kepada Badan Pertanahan Nasional atau Kelurahan setempat. Apabila sita jaminan (sita jaminan utama) telah menjadi sita eksekutorial dilelang atau sudah dieksekusi riil, maka sita persamaan dengan sendirinya menjadi hapus demi hukum. Apabila sita jaminan (sita jaminan utama) dicabut atau dinyatakan tidak berkuatan hukum, maka sita persamaan sesuai dengan urutannya menjadi sita jaminan (sita jaminan utama) (Mahkamah Agung Republik Indonesia, 2008:83-85).

Dengan adanya Sita Persamaan terhadap objek yang sedang dipersengketakan oleh pihak buruh maupun pihak bank sebagai pemegang hak tanggungan 
Nandang Sunandar, Kepastian Hukum Bank Eksekusi Objek Hak Tanggungan Yang Menjadi...

berkaitan

dengan

pembayaran/pelunasan

yang

didahulukan, maka objek tersebut akan dapat segera dilakukan eksekusi berdasarkan Sita Eksekusi (sita utama) terlebih dahulu oleh karena Sita Persamaan pada hakekatnya dapat dilaksanakan apabila Sita Jaminan atau Sita Eksekusi terlebih dahulu terpenuhi. Dengan demikian, bank sebagai pemegang hak tanggungan akan mendapatkan kepastian hukum.

\section{PENUTUP}

\section{Kesimpulan}

a. Kedudukan Bank dalam pelaksanaan eksekusi Hak Tanggungan yang objeknya menjadi sengketa ketenagakerjaan yaitu sebagai Kreditur Preference. Oleh karena itu Bank mempunyai hak untuk mendahului (hak preferensi) dan diutamakan dalam pembayaran atau pelunasan piutang dari kreditur-kreditur lainnya termasuk dalam hal ini pihak buruh. Hak preferensi merupakan hak mutlak yang diberikan oleh undang-undang terhadap pemegang hak tanggungan untuk melaksanakan eksekusi objek hak tanggungan dengan cara menjual obyek Hak Tanggungan atas kekuasaan sendiri melalui pelelangan umum serta mengambil pelunasan piutangnya dari hasil penjualan tersebut, apabila debitur telah dinilai melakukan wanprestasi sebagaimana diatur dalam Pasal 6 Undang-Undang No. 4 Tahun 1996 tentang Hak Tanggungan.

b. Pelaksanaan eksekusi Hak Tanggungan yang objeknya menjadi sengketa ketenagakerjaan tentunya terkendala terutama pada proses pelelangan objek hak tanggungan, sehingga proses eksekusi menjadi tidak dapat dijalankan sama sekali. Namun secara yuridis dengan mengacu pada ketentuan Pasal 20 ayat (1) 
huruf b Undang-Undang Hak Tanggungan, bahwa adanya sengketa ketenagakerjaan terhadap objek eksekusi hak tanggungan tidaklah mengakibatkan hak preferensi Bank sebagai pemegang hak tanggungan menjadi terdahului oleh pihak buruh. Walaupun Undang-Undang Nomor 13 Tahun 2003 tentang Ketenagakerjaan mengatur adanya hak preferensi bagi buruh. Akan tetapi hak preferensi tersebut, terbatas pada perusahaan dinyatakan pailit atau dilikuidasi berdasarkan peraturan perundang-undangan yang berlaku sebagaimana diatur dalam Pasal 95 ayat (4) UU Ketenagakerjaan. Oleh karena dari itu, adanya sengketa ketenagakerjaan terhadap pelaksanaan eksekusi hak tanggungan tidaklah mempunyai kekuatan hukum, dikarenakan adanya hak preferensi bank sebagai pemegang hak tanggungan yang terlebih dahulu telah dijamin keberadannya berdasarkan perjanjian kredit dan peraturan perundangundangan.

c. Kepastian hukum dalam eksekusi hak tanggungan yang objeknya menjadi sengketa ketenagakerjaan dapat diperoleh melalui adanya Diskresi Ketua Pengadilan Negeri Bandung sebagaimana diatur dalam Pasal 5 ayat (1) UndangUndang No. 48 Tahun 2009 tentang Kekuasaan Kehakiman yakni untuk melaksanakan musyawarah antara pihak bank dan pihak buruh untuk menetapkan eksekusi sita persamaan sebagaimana diatur dalam Pasal 463 Rv. Dengan adanya sita persamaan terhadap objek yang sedang dipersengketakan oleh pihak buruh maupun pihak bank sebagai pemegang hak tanggungan berkaitan dengan pembayaran/pelunasan yang 
Nandang Sunandar, Kepastian Hukum Bank Eksekusi Objek Hak Tanggungan Yang Menjadi...

$$
\begin{aligned}
& \text { didahulukan, maka objek } \\
& \text { tersebut akan dapat segera } \\
& \text { dilakukan eksekusi } \\
& \text { berdasarkan sita utama } \\
& \text { terlebih dahulu, karena sita } \\
& \text { persamaan pada hakekatnya } \\
& \text { dapat dilaksanakan apabila } \\
& \text { sita jaminan atau sita } \\
& \text { eksekusi terlebih dahulu } \\
& \text { terpenuhi. Dengan demikian, } \\
& \text { bank sebagai pemegang hak } \\
& \text { tanggungan akan } \\
& \text { mendapatkan kepastian } \\
& \text { hukum. }
\end{aligned}
$$

\section{Saran}

a. Sehubungan dengan kedudukan Bank pemegang Hak Tanggungan sebagai Kreditur Preference, maka diperlukan adanya sosialisasi kepada masyarakat

sehingga masyarakat dapat mengerti dan memahami haknya serta menghormati hak orang lain yang semuanya sama- sama dilindungi oleh hukum. Sosialisasi ini dapat dilakukan oleh pihak terkait dengan hukum, ketenagakerjaan, perguruan tinggi, Lembaga Swadaya Masyarakat, dan lain-lain.

b. Bank sebagai Pemegang Hak Tanggungan harus konsisten dan hati-hati dalam melaksanakan Prinsip $5 \mathrm{C}$ (Character, Capacity, Capital, Condition, Collateral), agar bank dapat meneliti secara seksama terhadap barang-barang yang akan dijadikan objek jaminan, baik mengenai aspek hukum maupun penguasaan fisiknya, sehingga akan terhindar dari kerugian yang akan timbul dikemudian hari. Kemudian berkaitan dengan pelaksanaan eksekusi, perlu dibentuknya peraturan pelaksanaan mengenai 
Nandang Sunandar, Kepastian Hukum Bank Eksekusi Objek Hak Tanggungan Yang Menjadi...

eksekusi Hak Tanggungan, agar pelaksanaan eksekusi dapat memberikan suatu kepastian hukum bagi kreditur/bank.

c. Perlu adanya peranan Ketua Pengadilan Negeri dalam hal ini Ketua Pengadilan Negeri Bandung untuk menyelesaikan persengketaan antara buruh dan bank sebagai pemegang hak tanggungan melalui Mediasi (ditemukannya buruh dan Bank untuk bermusyawarah) terhadap pelaksanaan eksekusinya, agar hasil penjualan terhadap objek sita eksekusi dan sita persamaan tersebut dibagikan sesuai dengan kesepakatan tersebut.

\section{DAFTAR PUSTAKA}

Agus Dwiyanto dkk, Reformasi Birokrasi Publik di Indonesia, Galang Pritika, Yogyakarta, 2002.

John Rawls, A Theory of Justice, Oxford University Press, London, Oxford, New York, 1973.

Mahkamah Agung Republik
Indonesia, Pedoman
Teknis Administrasi dan
Teknis Peradilan Perdata
Umum dan Perdata

Khusus, Buku II, Edisi 2007, Jakarta, 2008.

$\begin{array}{cr}\text { Mariam } \begin{array}{c}\text { Darus } \\ \text { Kerangka }\end{array} & \text { Badrulzman, } \\ \text { Jaminan Indonesia dalam } \\ \text { buku Hukum } & \text { Jaminan } \\ \text { Indonesia, } & \text { ELIPS, } \\ \text { Jakarta, 1998. } & \end{array}$

Muchsan, Beberapa catatan penting hukum administrasi negara dan peradilan administrasi negara di Indonesia, Liberty, Yogyakarta, 1981.

Muhammad Djumhana, Hukum Perbankan di Indonesia, Citra Aditya Bakti, Bandung, 2000.

Neufeldt, ed, tt, Webster New World, USA: Macmillan.

Prajudi Administrasi Atmosudirdjo, Manajemen Umum, Ghalia Indonesia, Jakarta, 1982.

Prakoso, Djoko, Polri Sebagai Penyidik dalam Penegakan Hukum, Bina Aksara, Jakarta, 1987.

Sjachran Basah, Eksistensi dan Tolok Ukur Badan Peradilan Administrasi di Indonesia, Alumni, Bandung, 1985.

Sutarno, Aspek-aspek Hukum Perkreditan Pada Bank, Alfabeta, Bandung, 2003. 
Nandang Sunandar, Kepastian Hukum Bank Eksekusi Objek Hak Tanggungan Yang Menjadi...

$\underline{\text { www.zuryawanisvandiarzoebir.blo }}$

gspot.com 